\title{
The Creation of State Institutions for Children without Parent Care, Period during King Zog Governance Up to Years 1990
}

\section{Orneda Gega (Hoxha)}

\author{
Faculty of Social Sciences, University of Tirana; ornedagega@gmail.com
}

\author{
Doi:10.5901/mjss.2016.v7n4p722
}

\begin{abstract}
The aim of this study is to make a research into historical context regarding the establishment of state institutions for children without parental care in Albania, during the period of time that was governed by King Zog till 1990s. This study is based on a historic qualitative study conducted for care institutions nationwide. The method that is used to collect data includes data obtained from the files of the Central State Archive. The study answered the following research questions: 1. What led to the adoption of orphan children the approval of a special provision in the period of Ahmet Zog?; 2. What changed with the creation of the Ministry of Education during the Second World War (1939-1945; 3. What were the reasons for the growth of infant mortality and the preventive measures?; 4. What contains the regulation of nests in 1950?; 5 . What were the measures that were taken in 1962 after the outcome of the report for the status of children of preschool and school? 6. What contained the relation for institutions that deals with vulnerable groups in 1989 ?
\end{abstract}

Keywords: legal provisions, mortality infant, regulations, relationship, preventive measures.

\section{Methodology}

The method that is use in this paper is the qualitative method. Through this method we provide the meaning and explanation of case studies, research facilities, the historical and philosophical viewpoint, collecting data and information in order to compare the cases or based on a single case study. (https://sq.wikipedia.org)

Historical method comprises the techniques and guidelines by which historians use primary sources and other data. The Albanian Central State Archive is used to realize this paper. For more than two months have been studied the files in order to clumped necessary information and to answers the questions of research.

Historical method has a wider scope than the comparative method, because it includes comparative reports (comparative) through periods of time when are made analyzes, bleaching stages of development, developmental levels, and so on. (http://www.slideshare.net/Menaxherat/metodologjia-kerkimore-shkencore-prof-dr-ali-jakupi)

Historical Method defines and identifies the events, to be able to answers to the questions: when, where, how, why, and under what circumstances are marked the events, and what is their cause and effect. The flaw of this method is that in many cases there is no relevant material, due to the lack of actual resources. (http://www.slideshare.net /Menaxherat/metodologjia-kerkimore-shkencore-prof-dr-ali-jakupi)

\section{Introduction}

In this study we will look step by step at how care institutions are built for children who have been left out of parental care. Compared to other periods, it is regarded as a more stable political period that of Ahmet Zog. After World War II, changes began with the creation of the Ministry of Social Welfare, which took over management of all institutions for categories in need. Occasionally, due to infant mortality, but in the context of improving the situation of orphans was necessary to make assessment reports and to take preventive measures.

\section{Findings of the Study}

In the years of the reign of Ahmet Zog, a more stable political situation, it would be accompanied by the approval of a specific legislative provision for admission in charitable institutions. "Following to circular Nr. 3278 / v d. 28 / XII / 1927 it was reported that after controlling permanent commission decision of the Red Cross, hereinafter every child that will be accepted at the shelter should not be older than the age of 14 years and submit the relevant documentation" . Parental 
power belonged to the father and only when he, though alive, cannot exercise it for different prohibitive reasons it then belonged to the mother. There were also improvements in the Civil Code, which regulates the recognition of maternity and paternity acknowledgment of a child born out marriage. Subsequent provisions allow adoption (adoption), provided that the adoptive parent at the time of the adoption had neither their own children nor legal descendants, and they have reached the age of forty years older than the person who was going to be adopted.

As seen orphanage conditions will be improved significantly during this period and by a circular of the Ministry of Interior dated 22. 05.1928 turn out that "today are being held with food, clothing and school over 130 orphans (girls and boys) from all provinces."

In 1929 the Archbishop of Durres urged the Council of Ministers to open an orphanage in Tirana."

World War II 1939-1945, in 1940 the collaborationist governments, despite the country faced the invader, tried to keep in better function the institutions of orphans. The situation in 1940 was being presented like that "the strength of students gathered was 350 persons, subdivided as follows: 125 in building no. 1, 125 in building no. 2 and 100 in building No. 3 and generally were 250 boys and 100 girls. The majority of these children attend the school "Naim Frasheri" for boys and "Luigi Gurakuqi" for girls. Everyone that ends primary school can attend school work or any private craft, if it's a boy. Girls can attend the internal affairs of dormitory or either School of Nursing. Shelter staff consists of 21 people.

With the creation of the Ministry of Social Assistance immediately all welfare institutions such as shelters, orphanages, nursing homes, etc. passed directly under its administration. Orphans left outside this institute went under the maintenance section of Social Assistance of the prefecture (Central Archives of the State Fund 5841945 File 188 Sheet no. 16). If you look at the geographic distribution of orphanages we will see that in 1945, schools of orphanages were widespread in the cities of Tirana, Durres, Shkodra, Korca, Vlora, Berat, Elbasan, Gjirokastra, Kukes. To become part of these schools by the Red Cross (Central State Archive Fund 1885841945 File Sheet no. 54) must be fulfilled these criteria: 1 . Children who are orphans without a father and without a mother or without one parent 2. Be poor and preferably of those injured in the war as children of martyrs. 3. Have an age not more than 7-9 years old. 4. To not have direct and indirect income from any near or supporter. 5 . To be healthy and have no infectious diseases, because such a thing would cause contamination of other children. The importance and attention to orphans, especially their housing, was emphasized by the Council of Ministers Decision no. 48 dated 15.03.1947 (Central State Archive Fund 9144991947 File Sheet no. 01) which inter alia stated that ... in our country should not have more homeless children, who walk along the streets as deserted by the fact that do not have parents and for these children should take care the state, which has the duty to care about children with no parents and take all necessary measures for their education. Thus, it was necessary to create an Executive Committee for the Prefectures and Sub / Prefectures whose aim would be housing. Each of the ministries was charged for children without parental care according to group-ages exactly the Ministry of Health care for 0-4 years, while the Ministry of Education for ages 4-14 years. What was put out was that education of work began after the age of 14 years, putting in work in state enterprises, on the farm or agricultural jobs in villages. One other important point had to do with the professional development of staff, taking charge in this direct way the Ministry of Education to develop vocational courses for employees of children's homes.

Another important task that had the Executive Committee (Central Archives of the State Fund 4991947 File 914 Sheet no. 02) was concerned with the fight against ill treatment that some parents do not educate their children and especially leave the children alone across the street. Given the above issues bore necessary to take these measures:

a) Prohibited children to engage in commerce, shoes painting, play in the street etc.

b) Prohibited children to beg, to smoke, drink alcohol, etc.

c) Prohibited children up to the age of 16 to enter restaurants, pubs, cafes and other premises where alcoholic beverages are drunk.

d) Prohibited children to go at night in the theater cinema unaccompanied

e) To be called to court and fined those who push their children to beg and trade.

Although efforts were being made to improve life for children without parental care, that in 1949 there was an increase in infant mortality. They highlighted as affecting the status of children, not good health, their unqualified personnel, psychological development of children lacking the latter as a result of deficient educational work as well as deficiency of toys. Given the above rule is added and types of children left without parental care were evident if far more children who had at least one parent already prevailed and categories such as; children abandoned at birth or children born out of wedlock. Given the increasing number of this category of children state that periods longer took the following measures:

1. Decision 829 (Central State Archive Fund 475121950 File Sheet no. 01) dated 10.02.1950 was decided that the mothers of these children have the right to be hospitalized with their children, provided if the mother breastfeed until the third month of birth. (Central State Archive Fund 475121950 File Sheet no. 07) 
2. Trying to find "tojat" who fed the children.

3. Provide fresh milk from the farm and shipped quickly.

4. Creating Health Institute farms so that nurseries supplied in order to choose the fresh brand

5. Providing fridges for the kindergartens

6. The greater dissemination of adoptions.

Also in the same year (1950) it was adopted a regulation for the permanent kindergartens, the first article of this regulation defined the goal for what this institution serves: " They served for the upbringing and education of young children, for the protection of children who do not have a possibility to grow up in the family environment or their position in the family circle puts at risk of getting sick from the disease." (Central State Archive Fund 475121950 Application File No. 02) The tape also determined that in these kindergartens accepted children from birth to three years of age, the conditions ${ }^{1}$ that must be met to become part of these kindergartens and how long can stay there.

But regardless regulation adopted state of permanent nests unfortunately was still poor. Thus, mortality high in foster permanent state of health, not the good of the children associated with many factors related to the situation in which sent some children in the nursery, the lack of breast milk, lack of clothing, with assisting not always good and sufficient by the staff. (Central State Archive Fund 355121951 File Sheet No.01)

As above it was necessary to 1962 was and a report on the state of housing the children of preschool and school in which are mentioned with that in our country we have 7 (seven) home baby with 570 children (Archives Central State Fund 1011, 1962 File No.01 sheet 43) What was striking was a different situation from the other, so one side would show devoted to the care of children to ensure the health and physical achievement in children and results from another presented a deficient situation in terms of educational work. The latter exactly condoned in underdeveloped skills psycho motor children, not recognize personal needs, do not know the names of the surrounding buildings, they were "outrageous", crouching when it came any new person, etc. This situation of children is adversely affected by the following factors: Children of the orphanage are abandoned children, child mothers are ill with tuberculosis, the state of the food is bad, children are physical as well as mental retardation, staff no professional preparation, caregivers do not communicate enough with children, toys, are missing etc.

According to what was mentioned above is necessary to improve the performance of orphanages it is necessary to organize training courses to prepare staff and ensure funds for toys.

Regarded to the orphanage at the age of preschool are counted four like that in our country in 1962, in which $85 \%$ of children who were admitted that came from orphanage and at this levels are shown positive and negative sides that have to do with children growth. Beginning/launched from issues it was necessary to strengthen the composition of the frame and work on its qualification, to ensure construction toys, visual and physical education (P.E) tools necessary for the overall development of children. On the other side the orphanage children come to develop the request of their age. (Central State Archive Fund in 1011, 1962 File 43 Sheet No.05)

In all country are counted 6 orphanages at the school age, what catches the eye in the previous homes is significant/big improvement in terms of educational works with children, children are educated with work habits and prepare them in profession such as tailoring, home economics etc. Despite the above problems appear again in systematic educational work, bringing stubbornly performances by children, lack of will and impatience to work, problem progress of children in school, insufficient staff compared with large number of children ${ }^{1}$ etc.

After being assessed the situation of infants and children homes (orphanage) it was necessary to fulfill the following tasks:

Central State Archive Fund in 1011, 1962 File 43 Sheet No.05

a) To draw up a work program for infant homes over the development of psychomotor children.

b) To publish literature in support of the preparation and training of staff

c) To reconstruct the locations etc

Ministry of Education and Culture (Central State Archive Fund in 1011, 1962 File 43, Sheet No.10) ${ }^{2}$

a) In cooperation with Ministry of Health to prepare cards for children where except noted health data and

\footnotetext{
${ }^{1}$ Note the conditions pertaining to: Children born out of wedlock or abandoned; Children orphaned or without a mother without a father or children who have only father and this economic condition; Children who are unable to increase the mother to mental illness or physical reasons and not another man in the house suitable site can hold; Children who have a family man in form tuberculosis that lives with; Children who are sick mother with diseases, or who have been hospitalized and at home have neither the appropriate person can keep the baby.

${ }^{2}$ Note: Educators group does not stay with the kids all the time that they are in the orphanages because she completes 8 (eight) hourses she leaves and children held only educator dërzhurnit, which for the large number of children who dependents can not develope educational work with them .
} 
psych-physical development of children from birth onwards, so that when children are transferred each be provided with this document.

b) Summer seminar with educators

c) Equipping orphanage children with toys.

According to the Protocol of the Presidency of the Council of Ministers for the state inspection report on the implementation of decisions of the Council of Ministers Nr. 72 dated 08.04.1970 (Central State Archive, Fund 512, 1973 File 164 Sheet No.01) (for children's homes, cautioned that the work of children's education should begin in kindergarten changing structure and adding educational personnel within existing organization charts. ${ }^{2 T h e}$ Presidency also added that all measures are taken to create environments for these children family with a mother and father and to learn by establishing rules and discipline ... .. In connection with staff to work in orphanages ${ }^{3}$ Chairman of the Council of Ministers held they are not only women but men so that children feel closer to the care of "mother" as well as the "father" be given the same education as all other children ..., the rule for children in orphanages will be held as school leavers 8 (eight) years, then either will attend high school, if they have conditions or be put to work and live or boarding bachelors or boarding school that will continue. 4-5-6-7-8 also the primary grades organize to become a little physical work 2-3 hours a day on a farm e.g. time after time and how to get work habits somewhat. The latter was highlighted more by the Chairman of the Council of Ministers which stated that this rule should be applied without any omission for boys and for girls, ... and if he does not go to work, then it will be taken administrative upon him, forcing him to work, .. (Central State Archive, Fund 512, 1973 File 164 sheet No.08)According statistics in 1981 presented in the following table with details of orphans accommodated in orphanages (Central State Archive, Fund 512, year 1981 File 257 Sheet No.01)

\begin{tabular}{|c|c|c|c|c|c|c|}
\hline Districts & Number of housing & Number of beds & Access during & Out during & Dead & $\begin{array}{l}\text { Number of children } \\
\text { at the end of the year }\end{array}$ \\
\hline 1. Durres & 1 & 200 & 85 & 62 & 4 & 94 \\
\hline 2. Korce & 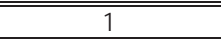 & 65 & 39 & 30 & 0 & 56 \\
\hline 3. Shkodra & 1 & 105 & 87 & 63 & 16 & 94 \\
\hline 4. Vlora & 1 & 85 & 14 & 19 & 0 & 55 \\
\hline 5. Tirana & 1 & 70 & 121 & 81 & 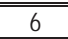 & 79 \\
\hline TOTAL & 5 & 525 & 346 & 255 & 26 & 378 \\
\hline
\end{tabular}

Employment matters and orphans gave DCM. 356 dated 09/09/1987 (Central State Archive, Fund 489, year 1989 File 109 Sheet No.52) for "upbringing and education of children in infant homes and child" in which it was decided that: Children who complete school medium low professional, within the month of May of each year be distributed Integrated Emergency arranged to work in various districts of the country from their ministries and central institutions and the ministry of Education. Communities Executive of the People's Councils of districts within the month of July each year to arrange these have, children priority in work under their profile and to provide pad or housing, the cost of food in the hostel after school until the appointment of a job be dealt with by the executive committee. Another important point concerned the boys who were forced military service directly after settling at work.

In 1989 again it became a summary report in which he includes information about institutions dealing with children, adults and seniors with the social problem of mental illness, which had to do with the goal to improve the work with these categories.

And in our country in this year worked five (5) houses a baby under the Ministry of Health, 2 (two) home for preschool children and three (3) home for children who are in school (Archive Central State Fund 489, year 1989 File 109 sheet No. 5). What periods longer be observed in this was that the number of children born out of marriages decreased, the latter occurred as a result of increasing adoptions and illegal abortions. After an evaluation of the conclusion that the in these institutions as a whole made a good job, so the homes of infant mortality was zero and morbidity is very low, also have taken measures to improved development work psychomotor children deciding educators qualified, problem considering that these institutions are held and children who do not speak hear.

\section{Conclusions}

For orphans adoption of a provision of the special legislative in the period of Ahmet Zog led to the establishment of new criteria for admission of children to Orphanage also approved that the power of parental belonged to my father, it was decided Date a maternity and paternity child born out of wedlock, adoption of children allowed.

The creation of the Ministry of Education during World War II (1939-1945) made possible for the welfare institutes 
as shelters, orphanages, nursing homes, etc. to pass directly under its management and administration.

The reasons that in 1949 increased infant mortality dealt with, not good health of their not qualified staff, delayed development of children, lacked tools and entertainment development.

In 1950, the nursery was adopted regulations which, inter alia, determines the criteria's age for admission to nursery that was the age of three conditions that must be met to become part of these kindergartens and the period until they could stay there.

In 1962 after the results of the Report on the status of children of preschool and school was necessary to handle such measures: to become the program of work for home baby on the development of children, to qualify employees through the publication of literature and implementation seminars etc.

In the institutions dealing with disadvantaged groups in 1989 say that was making a commendable job by a baby mortality rare respect to zero setting, reducing morbidity in by country sour qualified educators.

\section{References}

Central State Archive Fund 1885841945 Application File no. 16

Central State Archive Fund 1885841945 Application File no. 54 Central State Archive Fund 9144991947 Application File no. 01 Central State Archive Fund 9144991947 Application File no. 02 Central State Archive Fund 475121950 Application File no. 01 Central State Archive Fund 475121950 Application File no. 07 Central State Archive Fund 475121950 File Sheet No. 02 Central State Archive Fund 355121951 Application File No.01 Central State Archive Fund in 1011, 1962 File 43 Sheet No.01 Central State Archive Fund in 1011, 1962 File 43 Sheets No. 05 Central State Archive Fund in 1011, 1962 File 43 Sheets No. 09 Central State Archive Fund in 1011, 1962 File 43 Sheets No. 10 Central State Archive, Fund 512, 1973164 sheets File No.01 Central State Archive, Fund 512, 1973 File 164 Sheets No. 04 Central State Archive, Fund 512, 1973164 sheets File No.08 Central State Archive, Fund 512, year 1981 File 257 Sheet No.01 Central State Archive, Fund 489, year 1989 File 109 Sheet No. 52 Central State Archive, Fund 489, year 1989 File 109 Sheet No. 5 